\title{
Article \\ Fibrin-Plasma Rich in Growth Factors Membrane for the Treatment of a Rabbit Alkali-Burn Lesion
}

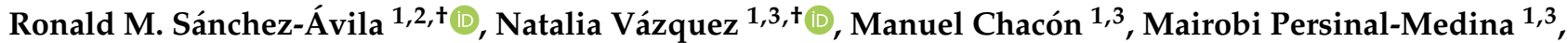 \\ Agustín Brea-Pastor 4 , Silvia Berisa-Prado 1, Luis Fernández-Vega-Cueto 1,3, Eduardo Anitua 2,5, \\ Álvaro Meana ${ }^{1,3,6, *(\mathbb{D})}$ and Jesús Merayo-Lloves ${ }^{1,3}$ (D)
}

\section{check for} updates

Citation: Sánchez-Ávila, R.M.; Vázquez, N.; Chacón, M.; PersinalMedina, M.; Brea-Pastor, A.; BerisaPrado, S.; Fernández-Vega-Cueto, L.; Anitua, E.; Meana, Á.; Merayo-Lloves, J. Fibrin-Plasma Rich in Growth Factors Membrane for the Treatment of a Rabbit Alkali-Burn Lesion. Int. J. Mol. Sci. 2021, 22, 5564. https:// doi.org/10.3390/ijms22115564

Academic Editor: Akiko Maeda

Received: 4 May 2021

Accepted: 20 May 2021

Published: 25 May 2021

Publisher's Note: MDPI stays neutral with regard to jurisdictional claims in published maps and institutional affiliations.

Copyright: (c) 2021 by the authors. Licensee MDPI, Basel, Switzerland. This article is an open access article distributed under the terms and conditions of the Creative Commons Attribution (CC BY) license (https:// creativecommons.org/licenses/by/ $4.0 /)$
1 Instituto Universitario Fernández-Vega, Fundación de Investigación Oftalmológica, Universidad de Oviedo, 33071 Oviedo, Spain; ronald.sanchezavila@gmail.com (R.M.S.-Á.); natalia.vazquez@fio.as (N.V.); m.chacon@fio.as (M.C.); mairobimedina@gmail.com (M.P.-M.); sberisap@gmail.com (S.B.-P.); lfvc@fernandez-vega.com (L.F.-V.-C.); merayo@fio.as (J.M.-L.)

2 Biotechnology Institute (BTI), 01007 Vitoria, Spain; eduardoanitua@eduardoanitua.com

Instituto de Investigación Sanitaria del Principado de Asturias (ISPA), 33071 Oviedo, Spain

4 Unidad de Bioterio e imagen Preclínica, Universidad de Oviedo, 33071 Oviedo, Spain; vetuniovi@gmail.com

5 University Institute for Regenerative Medicine and Oral Implantology (UIRMI), 01007 Vitoria, Spain

6 Centro de Investigación Biomédica en Red en Enfermedades Raras (CIBERER) (U714), ISCII, 28029 Madrid, Spain

* Correspondence: meana@fio.as; Tel.: +34-985-240-141; Fax: +34-985-233-288

+ These authors have contributed equally to this work.

Abstract: The purpose of this work is to describe the use of Fibrin-Plasma Rich in Growth Factors (PRGF) membranes for the treatment of a rabbit alkali-burn lesion. For this purpose, an alkali-burn lesion was induced in 15 rabbits. A week later, clinical events were evaluated and rabbits were divided into five treatment groups: rabbits treated with medical treatment, with a fibrin-PRGF membrane cultured with autologous or heterologous rabbit Limbal Epithelial Progenitor Cells (LEPCs), with a fibrin-PRGF membrane in a Simple Limbal Epithelial Transplantation and with a fibrin-PRGF membrane without cultured LEPCs. After 40 days of follow-up, corneas were subjected to histochemical examination and immunostaining against corneal or conjunctival markers. Seven days after alkali-burn lesion, it was observed that rabbits showed opaque cornea, new blood vessels across the limbus penetrating the cornea and epithelial defects. At the end of the follow-up period, an improvement of the clinical parameters analyzed was observed in transplanted rabbits. However, only rabbits transplanted with cultured LEPCs were positive for corneal markers. Otherwise, rabbits in the other three groups showed positive staining against conjunctival markers. In conclusion, fibrin-PRGF membrane improved the chemically induced lesions. Nonetheless, only fibrin-PRGF membranes cultured with rabbit LEPCs were able to restore the corneal surface.

Keywords: in vitro expansion; limbal stem cell; alkali-burn lesion; fibrin-PRGF membrane; PRP

\section{Introduction}

Ocular chemical burns are one of the most devastating situations for the ophthalmologist, which require an immediate and intensive evaluation and treatment $[1,2]$. Chemical burns to the eye or ocular adnexa are responsible for 11.5-22.1\% of ocular injuries [3] and have potentially relevant long-term consequences to the vision and overall quality of life [4-7]. Most injuries occur in young men, and exposure results from accidents at work, at home, or during an assault [2,8].

Acidic or alkaline agents usually cause ocular chemical burns. Alkaline substances are more damaging to the eye than acidic substances because they have the inherent ability to penetrate the ocular structures due to their hydrophilic and lipophilic properties [5,9]. The deleterious effect of caustication depends on the nature and type of substance involved, as well as the length of time the substance was in contact with the eye [10], being the 
extent of ocular surface damage one of the most important prognostic factors for the visual outcome [1,2,9,11-13].

Several medical treatments and different surgical procedures (amniotic membrane, penetrating keratoplasty, keratoprosthesis) have been used for the treatment of ocular alkali-burns $[2,14,15]$. Their success rate being conditioned by the phase of the disease: immediate, acute, early repair and late repair [16], but also by the amount of limbal involvement at the time of the injury.

The limbus is the transitional zone between the sclera and the cornea where epithelial corneal stem cells are located [17-22]. The limbus is responsible for renewing the corneal epithelium and acts as a barrier between cornea and conjunctiva, preventing the migration of conjunctival epithelium [21,23]. Limbal stem cell depletion or dysfunction, Limbal Stem Cell Deficiency (LSCD), leads to the loss of the corneal regenerative capacity but also allows conjunctival epithelium to invade the corneal surface leading to opacification, vascularization, the appearance of persistent epithelial defects and inflammation [24]. Clinically, patients present pain, photophobia, loss of vision and blindness in advanced cases.

LSCD has a multifactorial etiology with several primary or secondary causes, with severe chemical burns being a common cause of this disease $[14,20,25]$. The treatment of LSCD depends on the extent of the affected limbal area. In the case of minor limbal involvement, mechanical debridement of the conjunctival epithelium, whether or not associated to the use of an amniotic membrane, can be enough to restore the corneal surface due to remnant cells of the healthy limbal area [26]. However, in the case of extensive limbal area involvement, treatments range from grafting of contralateral, live related, or cadaveric limbal tissue [27-29] to transplant cultured cells of different origin: cornea, oral mucosa and mesenchymal stem cells [30-35] or grafting of small pieces of limbal explants directly onto the ocular surface [36-40].

Human amniotic and fibrin membranes are commonly used in the latter two procedures as a substrate providing support to the transplanted cells or limbal explants, respectively [41,42]. Alternative carrier materials have been studied for the transplantation of cultured cells, including coated contact lenses [43], compressed collagen [44] and synthetic membranes [45]. However, these materials have inconveniences such as the threat of transmission of animal-derived pathogens, donor tissue-derived infections or high cost [46].

Plasma Rich in Growth Factors (PRGF) is an autologous platelet-rich plasma that contains a greater number of growth factors than the human serum and other platelet-rich plasmas, which has great versatility, allowing the preparation of different therapeutic formulations including eye drops and fibrin clots [47]. In ophthalmology, fibrin-PRGF membranes have shown effective results when employed as adjuvant treatment in human ocular surface repair [48,49] and as a scaffold [50] for culturing and delivering human Limbal Epithelial Progenitor Cells (LEPCs). However, in the last years, several studies have demonstrated controversial results in the effect of platelet-rich plasmas to promote wound healing and tissue regeneration [51,52]. One reason might be the variability in the preparation protocols that results in distinctive formulations and properties $[53,54]$.

This work aims to prove the efficacy of fibrin-PRGF fibrin membranes to treat an alkaliburn lesion in an animal model with different therapeutic approaches. For this purpose, we studied the transplant of in vitro expanded autologous and heterologous LEPCs on fibrin-PRGF membranes, the Simple Limbal Epithelial Transplantation (SLET) technique with a fibrin-PRGF membrane and the role of the fibrin-PRGF membrane without cultured cells as adjuvant therapy.

\section{Results}

\subsection{Cell Culture}

After two days of culture, LEPCs began to migrate from the limbal explants to the culture plate. Cells were flat and round, forming a monolayer immediately adjacent to the explant. After five days, cultures were semiconfluent, and cells were trypsinized and subcultured onto rabbit fibrin-PRGF membranes (groups 2 and 3). These membranes 
were able to support the cellular growth of rabbit LEPCs while displaying their typical polyhedral morphology. Moreover, immunofluorescence analysis showed that LEPCs expressed a positive stain against the p63 marker (Figure 1).
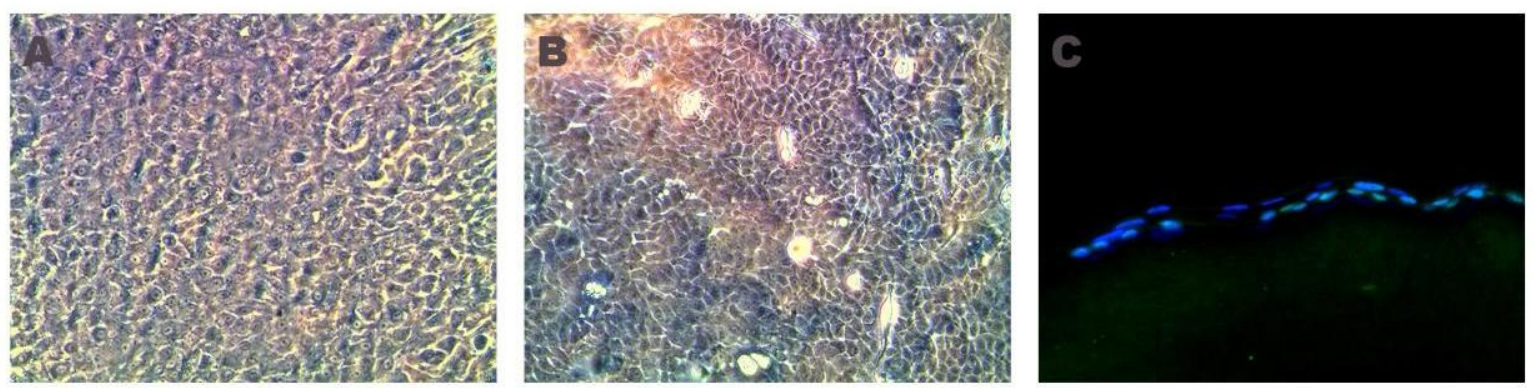

Figure 1. Phase-contrast microscopy of autologous (A) or heterologous (B) rabbit LEPCs cultured on a fibrin-PRGF membrane displaying their typical polyhedral morphology. Immunofluorescence analysis of fibrin-PRGF membranes cultured with rabbit LEPCs for p63 in green and DAPI in blue (C). 100× (phase-contrast microscopy) and 400× (immunofluorescence).

\subsection{Rabbit Alkali-Burn Lesion}

Seven days after the alkali-burn lesion, all rabbits showed opaque cornea, new blood vessels across the limbus penetrating the cornea, and epithelial defects shown by fluorescein stain (Figure 2).

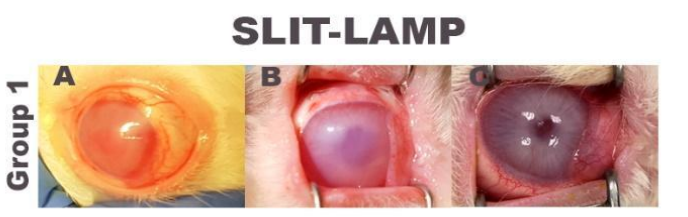

\section{FLUORESCEIN STAIN}
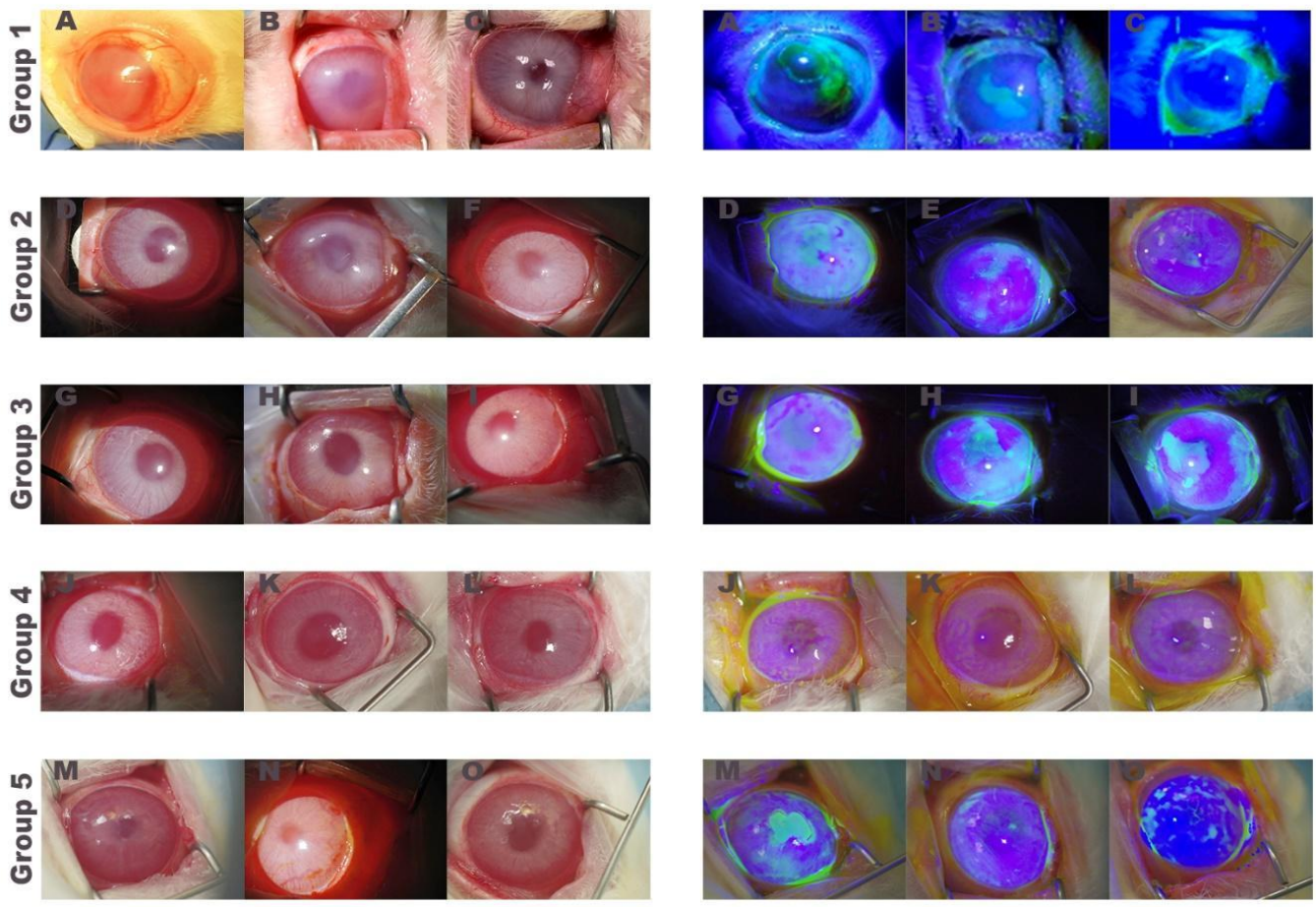

Figure 2. Appearance of rabbit eyes seven days after alkali-burn lesion. Slit-lamp photographs (left) and fluorescein stain photographs (right) of the three treated rabbits of each group. Group 1: only medical treatment (control group), Group 2: fibrin-PRGF membrane cultured with autologous rabbit LEPCs, Group 3: fibrin-PRGF membrane cultured with heterologous rabbit LEPCs, Group 4: fibrin-PRGF membrane SLET and Group 5: fibrin-PRGF membrane without rabbit cultured LEPCs. PRGF: Plasma Rich in Growth Factors; LEPCs: Limbal Epithelial Progenitor Cells; SLET: Simple Limbal Epithelial Transplantation. 
Results of clinical evaluation (Table 1) showed that all groups had a mild haze or moderately/severely dense corneal opacity (scores $2-4$ ); with $>1 / 4$ of corneal neovascularization (scores 2-4), 2-4 fibrovascular pannus (scores 2 to 4), except one rabbit in the control group (score 1), and epithelial defects affecting up to $75 \%$ of the corneal surface (scores 1-3). No significant differences were found between the scores of all groups in the four clinical parameters analyzed.

Table 1. Clinical evaluation of the rabbits the day of the evaluation and treatment. S0-S4: scores defined in Table 4.

\begin{tabular}{|c|c|c|c|c|c|c|c|c|c|c|c|c|c|c|c|c|c|c|c|c|c|}
\hline & \multirow[b]{2}{*}{ Rabbits } & \multicolumn{5}{|c|}{ Corneal Opacification } & \multicolumn{5}{|c|}{ Corneal Neovascularization } & \multicolumn{5}{|c|}{ Fibrovascular Pannus } & \multicolumn{5}{|c|}{ Epithelial Defects } \\
\hline & & So & S1 & S2 & S3 & $\mathrm{S} 4$ & So & S1 & S2 & S3 & $\mathrm{S} 4$ & So & S1 & $\mathrm{S} 2$ & S3 & S4 & So & S1 & S2 & S3 & S4 \\
\hline \multirow{3}{*}{ Group 1} & 1 & & & & & • & & & & $\bullet$ & & & & • & & & & & & $\bullet$ & \\
\hline & 2 & & & & $\bullet$ & & & & • & & & & & $\bullet$ & & & & & • & & \\
\hline & 3 & & & $\bullet$ & & & & & $\bullet$ & & & & $\bullet$ & & & & & $\bullet$ & & & \\
\hline \multirow{3}{*}{ Group 2} & 4 & & & & • & & & & & • & & & & & • & & & • & & & \\
\hline & 5 & & & & & • & & & & & $\bullet$ & & & & & $\bullet$ & & & & • & \\
\hline & 6 & & & & $\bullet$ & & & & & & $\bullet$ & & & & $\bullet$ & & & & $\bullet$ & & \\
\hline \multirow{3}{*}{ Group 3} & 7 & & & & • & & & & & • & & & & & • & & & $\bullet$ & & & \\
\hline & 8 & & & • & & & & & & & • & & & & & • & & & & • & \\
\hline & 9 & & & & • & & & & & & • & & & & $\bullet$ & & & & & $\bullet$ & \\
\hline \multirow{3}{*}{ Group 4} & 10 & & & & • & & & & & & $\bullet$ & & & • & & & & $\bullet$ & & & \\
\hline & 11 & & & $\bullet$ & & & & & & $\bullet$ & & & & $\bullet$ & & & & & $\bullet$ & & \\
\hline & 12 & & & & $\bullet$ & & & & & & $\bullet$ & & & & & $\bullet$ & & & $\bullet$ & & \\
\hline \multirow{3}{*}{ Group 5} & 13 & & & & • & & & & & & • & & & & • & & & & & $\bullet$ & \\
\hline & 14 & & & & • & & & & & & • & & & & • & & & & & • & \\
\hline & 15 & & & $\bullet$ & & & & & & • & & & & & $\bullet$ & & & & • & & \\
\hline
\end{tabular}

Group 1: only medical treatment (control group), Group 2: fibrin-PRGF membrane cultured with autologous rabbit LEPCs, Group 3: fibrin-PRGF membrane cultured with heterologous rabbit LEPCs, Group 4: fibrin-PRGF membrane SLET and Group 5: fibrin-PRGF membrane without rabbit cultured LEPCs. PRGF: Plasma Rich in Growth Factors, LEPCs: Limbal Epithelial Progenitor Cells, SLET: Simple Limbal Epithelial Transplantation.

\subsection{Clinical Outcome Analysis}

All rabbits were evaluated once a week and at the end of the follow-up period (Figure 3).

Results of the clinical evaluation (Table 2) showed that rabbits treated only with medical treatment (control group) retained or worsened the initial clinical diagnosis, with rabbit number one having the most severe degree of corneal opacification, vascularization, and epithelial defects.

In contrast, rabbits in the other treatment groups improved the initial clinical diagnosis. Comparing the final and initial clinical evaluation, this improvement was different between groups. Rabbits transplanted with autologous or heterologous rabbit LEPCs (groups 2 and 3) and rabbits transplanted with fibrin-PRGF membrane SLET (group 4) showed a totally clear cornea (score 0), and only in two cases (in rabbit number two of groups 2 and 4) a mild haze (score 2) was observed. In the case of the rabbits transplanted with fibrin-PRGF membrane without rabbit cultured LEPCs (group 5), all the rabbits showed a haze of minimal density (score 1). Similarly, all transplanted rabbits showed no epithelial defects (score 0 ) or epithelial defects that affect less than $1 / 4$ of the corneal surface (score 1 ). 
SLIT-LAMP
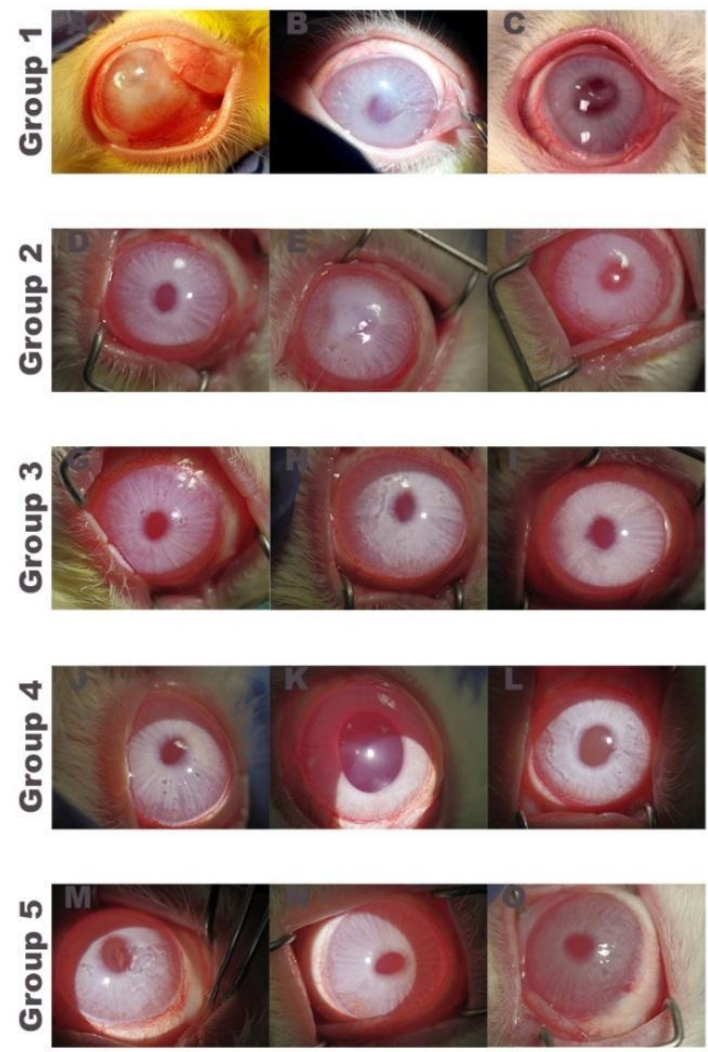

FLUORESCEIN STAIN
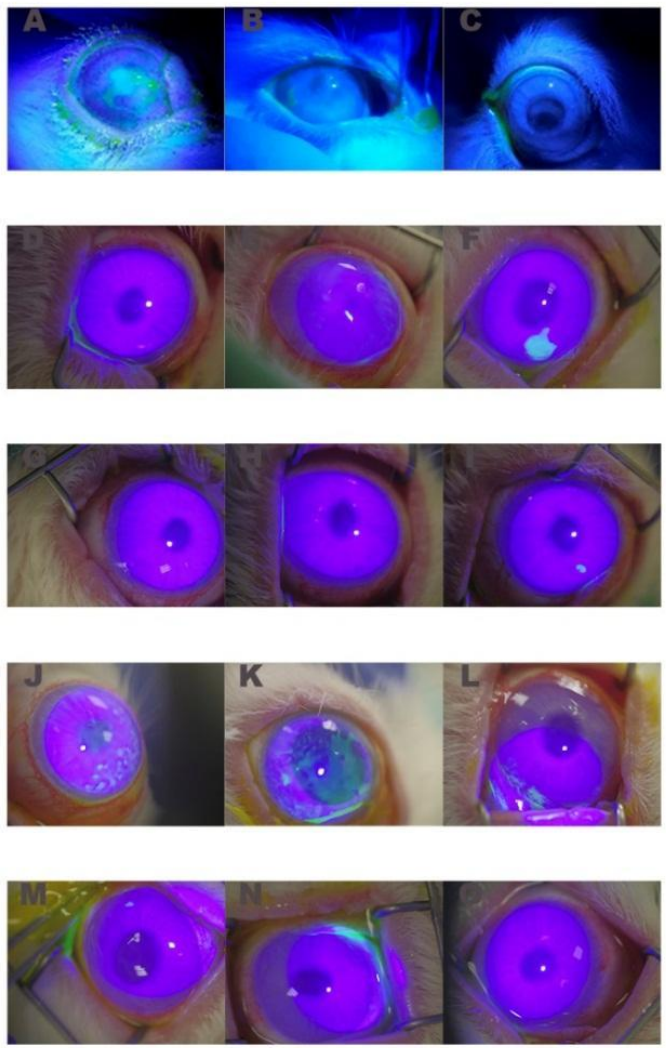

Figure 3. Appearance of rabbit eyes at the end of the follow-up period. Slit-lamp photographs (left) and fluorescein stain photographs (right) of the three treated rabbits of each group. Group 1: only medical treatment (control group), Group 2: fibrin-PRGF membrane cultured with autologous rabbit LEPCs, Group 3: fibrin-PRGF membrane cultured with heterologous rabbit LEPCs, Group 4: fibrin-PRGF membrane SLET and Group 5: fibrin-PRGF membrane without rabbit cultured LEPCs. PRGF: Plasma Rich in Growth Factors; LEPCs: Limbal Epithelial Progenitor Cells; SLET: Simple Limbal Epithelial Transplantation.

Table 2. Clinical evaluation of the rabbits on the day of the diagnosis and treatment and at the end of the follow-up period. S0-S4: scores defined in Table 4.

\begin{tabular}{|c|c|c|c|c|c|c|c|c|c|c|c|c|c|c|c|c|c|c|c|c|c|}
\hline & \multirow[b]{2}{*}{ Rabbits } & \multicolumn{5}{|c|}{ Corneal Opacification } & \multicolumn{5}{|c|}{ Corneal Neovascularization } & \multicolumn{5}{|c|}{ Fibrovascular Pannus } & \multicolumn{5}{|c|}{ Epithelial Defects } \\
\hline & & So & S1 & S2 & S3 & S4 & So & S1 & S2 & S3 & S4 & So & S1 & S2 & S3 & S4 & So & S1 & S2 & S3 & S4 \\
\hline Group 1 & $\begin{array}{l}1 \\
2 \\
3\end{array}$ & & & $\stackrel{\diamond}{\bullet / \diamond}$ & $\bullet$ & $\bullet / \diamond$ & & & $\begin{array}{l}\bullet / \Delta \\
\bullet / \Delta\end{array}$ & • & $\diamond$ & & $\bullet / \diamond$ & $\bullet$ & $\diamond$ & & & $\stackrel{\diamond}{\bullet / \diamond}$ & $\bullet$ & & $\diamond$ \\
\hline Group 2 & $\begin{array}{l}4 \\
5 \\
6\end{array}$ & $\begin{array}{l}\diamond \\
\diamond\end{array}$ & & $\diamond$ & $\begin{array}{l}\bullet \\
\bullet\end{array}$ & • & & $\begin{array}{l}\diamond \\
\diamond\end{array}$ & $\diamond$ & • & $\bullet$ & $\diamond$ & $\diamond$ & & $\begin{array}{l}\bullet \\
\bullet \\
\bullet\end{array}$ & & $\begin{array}{l}\diamond \\
\diamond\end{array}$ & $\begin{array}{l}\cdot \\
\diamond\end{array}$ & • & • & \\
\hline Group 3 & $\begin{array}{l}7 \\
8 \\
9\end{array}$ & $\begin{array}{l}\diamond \\
\diamond \\
\diamond\end{array}$ & & $\bullet$ & $\begin{array}{l}\bullet \\
\bullet\end{array}$ & & & $\begin{array}{l}\vartheta^{\prime} \\
\diamond\end{array}$ & $\diamond$ & • & • & $\diamond$ & $\begin{array}{l}\diamond \\
\diamond\end{array}$ & & $\begin{array}{l}\bullet \\
\bullet\end{array}$ & $\bullet$ & $\begin{array}{l}\diamond \\
\diamond\end{array}$ & $\begin{array}{l}\bullet \\
\bullet\end{array}$ & & • & \\
\hline Group 4 & $\begin{array}{l}10 \\
11 \\
12\end{array}$ & $\begin{array}{l}\diamond \\
\diamond\end{array}$ & & $\bullet / \diamond$ & $\begin{array}{l} \\
\bullet \\
\bullet\end{array}$ & & & & $\diamond$ & 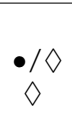 & $\begin{array}{l} \\
\bullet\end{array}$ & $\diamond$ & $\diamond$ & $\dot{\bullet}$ & & • & $\diamond$ & $\begin{array}{l}\dot{\bullet} \\
\dot{\diamond}\end{array}$ & • & & \\
\hline Group 5 & $\begin{array}{l}13 \\
14 \\
15\end{array}$ & & $\begin{array}{l}\diamond \\
\diamond \\
\diamond\end{array}$ & . & • & & & & $\diamond$ & $\begin{array}{c}\diamond \\
\bullet / \diamond\end{array}$ & • & & $\diamond$ & $\begin{array}{l}\diamond \\
\diamond\end{array}$ & $\dot{\bullet}$ & & $\diamond$ & $\begin{array}{l}\diamond \\
\diamond\end{array}$ & • & $\stackrel{\bullet}{\bullet}$ & \\
\hline
\end{tabular}

$\bullet$ : pre-treatment; $\diamond:$ post-treatment. Group 1: only medical treatment (control group), Group 2: fibrin-PRGF membrane cultured with autologous rabbit LEPCs, Group 3: fibrin-PRGF membrane cultured with heterologous rabbit LEPCs, Group 4: fibrin-PRGF membrane SLET and Group 5: fibrin-PRGF membrane without rabbit cultured LEPCs. PRGF: Plasma Rich in Growth Factors; LEPCs: Limbal Epithelial Progenitor Cells; SLET: Simple Limbal Epithelial Transplantation. 
The major differences between groups were observed in the neovascularization and in the number of fibrovascular pannus. In the case of the neovascularization area, the rabbits transplanted with autologous (group 2) or heterologous (group 3) rabbit LEPCs showed an improvement, reducing the affected corneal area by half (from score 3 or 4 to score 1 or 2). In the case of rabbits transplanted with fibrin-PRGF membrane SLET (group 4) and rabbits transplanted with fibrin-PRGF membrane without rabbit cultured LEPCs (group 5), this improvement was not so evident, with one rabbit maintaining the same vascularization (score 3 ) and two rabbits decreased the vascularized corneal area (score 4 to score 2 or 3). Finally, the improvement in the number of fibrovascular pannus was again most evident in rabbits transplanted with cultured LEPCs (groups 2 and 3), showing a decrease from score 3 or 4 to score 0 or 1 . The other groups, rabbits transplanted with fibrin-PRGF membrane SLET (group 4) and rabbits transplanted with fibrin-PRGF membrane without rabbit cultured LEPCs (group 5), also reduced the number of fibrovascular pannus, but to a lesser extent.

One corneal edema was observed in rabbit number two transplanted with fibrin-PRGF membrane cultured with autologous LEPC (group 2).

On the other hand, the percentage of change before and after treatment for each clinical variable measured was compared between the groups (Table 3 ). Statistically significant differences $(p<0.05)$ were found in corneal neovascularization and fibrovascular pannus, between rabbits transplanted with fibrin-PRGF membrane cultured with autologous (group 2) or heterologous (group 3) rabbit LEPCs, and rabbits treated with only medical treatment (group 1).

Table 3. Percentage of change before and after treatment for each clinical variable measured. Data are shown as mean \pm standard deviation (SD).

\begin{tabular}{ccccc}
\hline & Corneal Opacification & Corneal Neovascularization & Fibrovascular Pannus & Epithelial Defects \\
\hline Group 1 & $-11.11 \pm 19.25$ & $11.11 \pm 19.25$ & $16.67 \pm 28.87$ & $-5.56 \pm 41.94$ \\
\hline Group 2 & $-83.33 \pm 28.87$ & $-63.89 \pm 12.73^{\dagger}$ & $-80.56 \pm 17.35^{\dagger}$ & $-83.33 \pm 28.87$ \\
\hline Group 3 & $-100.00 \pm 00.00$ & $-63.89 \pm 12.73 \ddagger$ & $-80.56 \pm 17.35 \ddagger$ & $-88.89 \pm 19.25$ \\
\hline Group 4 & $-66.67 \pm 57.74$ & $-25.00 \pm 25.00$ & $-66.67 \pm 28.87$ & $-66.67 \pm 28.87$ \\
\hline Group 5 & $-61.11 \pm 9.62$ & $-25.00 \pm 25.00$ & $-44.44 \pm 19.25$ & $-72.22 \pm 25.46$ \\
\hline$p$-value & 0.079 & $0.032 *$ & $0.040^{*}$ & 0.126 \\
\hline
\end{tabular}

* Statistically significant difference $(p<0.05)$ between groups. $\dagger$ and $\ddagger$, statistically significant difference $(p<0.05)$ between rabbits treated with fibrin-PRGF membrane cultured with autologous (group 2) or heterologous (group 3) rabbit LEPCs and control group. Group 1: only medical treatment (control group), Group 2: fibrin-PRGF membrane cultured with autologous rabbit LEPCs, Group 3: fibrin-PRGF membrane cultured with heterologous rabbit LEPCs, Group 4: fibrin-PRGF membrane SLET and Group 5: fibrin-PRGF membrane without rabbit cultured LEPCs. PRGF: Plasma Rich in Growth Factors; LEPCs: Limbal Epithelial Progenitor Cells; SLET: Simple Limbal Epithelial Transplantation.

\subsection{Histology and Immunocytochemistry}

Results of the histological evaluation (Figure 4) showed that rabbits treated only with medical treatment (control group) had the limbus area invaded with a conjunctival epithelium characterized by the presence of goblet cells. In the peripheral and central cornea, an abnormal epithelium with a few layers of epithelial cells, ulcers, blood vessels in the underlying stroma and inflammatory cell infiltration were observed in all rabbits in this group.

In contrast, rabbits transplanted with autologous (group 2) or heterologous (group 3) rabbit LEPCs had a normal cornea with a multilayered peripheral and central epithelium with 3-5 layers of epithelial cells, with a slight inflammatory cell infiltration on the matrix and the limbal area showed a normal morphology without the presence of goblet cells. A small peripheral ulcer was observed in rabbit number three of both groups (data are not shown). 


\section{LIMBUS}
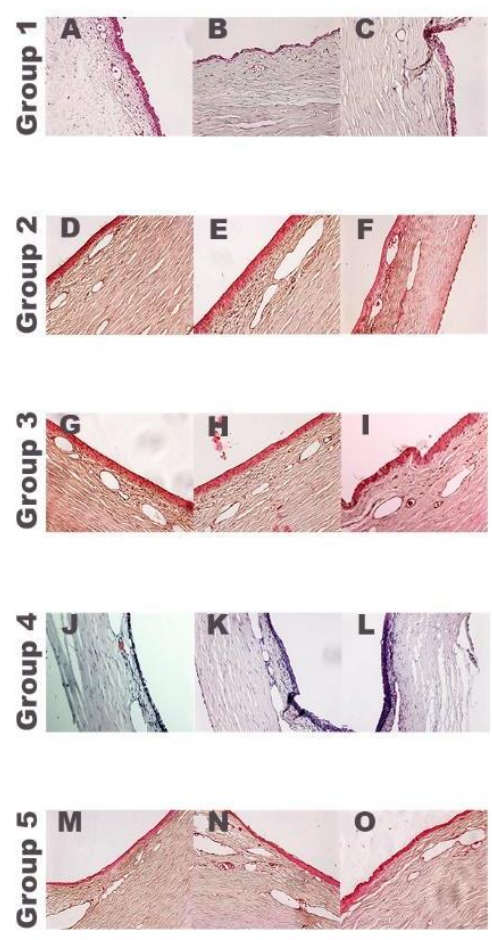

PERIPHERAL CORNEA
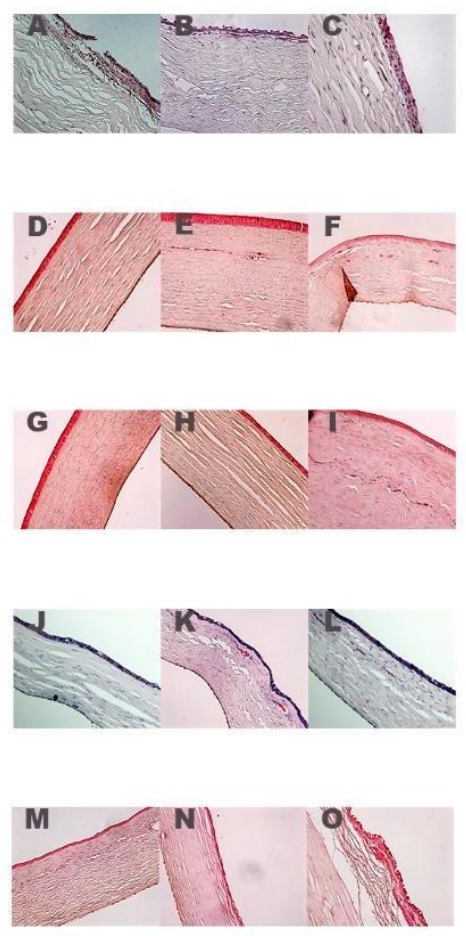

\section{CENTRAL CORNEA}
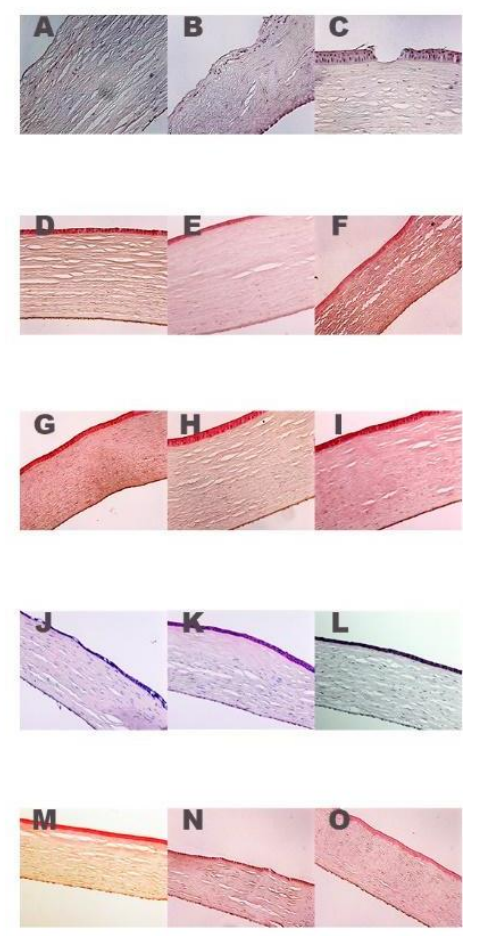

Figure 4. Histological analysis of rabbit corneas. Hematoxylin-eosin photographs of the three treated rabbits' corneas of each group. Group 1: only medical treatment (control group), Group 2: fibrin-PRGF membrane cultured with autologous rabbit LEPCs, Group 3: fibrin-PRGF membrane cultured with heterologous rabbit LEPCs, Group 4: fibrin-PRGF membrane SLET and Group 5: fibrin-PRGF membrane without rabbit cultured LEPCs. 200×. PRGF: Plasma Rich in Growth Factors; LEPCs: Limbal Epithelial Progenitor Cells; SLET: Simple Limbal Epithelial Transplantation.

However, in the groups of rabbits transplanted with fibrin-PRGF membrane SLET (group 4) and rabbits transplanted with only fibrin-PRGF membrane (group 5), the limbal area included goblet cells penetrating in the peripheral (both groups) and central cornea (rabbit number one of group 4). A small peripheral ulcer was observed in rabbit number three treated with fibrin-PRGF membrane without rabbit cultured LEPC (data are not shown). In the rest of the rabbits, the appearance of the central cornea was normal, in both groups.

Immunofluorescence analysis (Figure 5) corroborated the histological analysis showing positive stain against MUC5ac in the limbal area of rabbits treated only with medical treatment (control group), rabbits transplanted with fibrin-PRGF membrane SLET (group 4) and rabbits transplanted with fibrin-PRGF membrane without rabbit cultured LEPCs (group 5). P63 expression was found mainly in the nucleus of the basal layer and a few in the suprabasal layer of the limbal epithelium in the groups of rabbits transplanted with autologous (group 2) or heterologous (group 3) LEPCs. 


\section{LIMBUS (p63 or MUC5ac)}
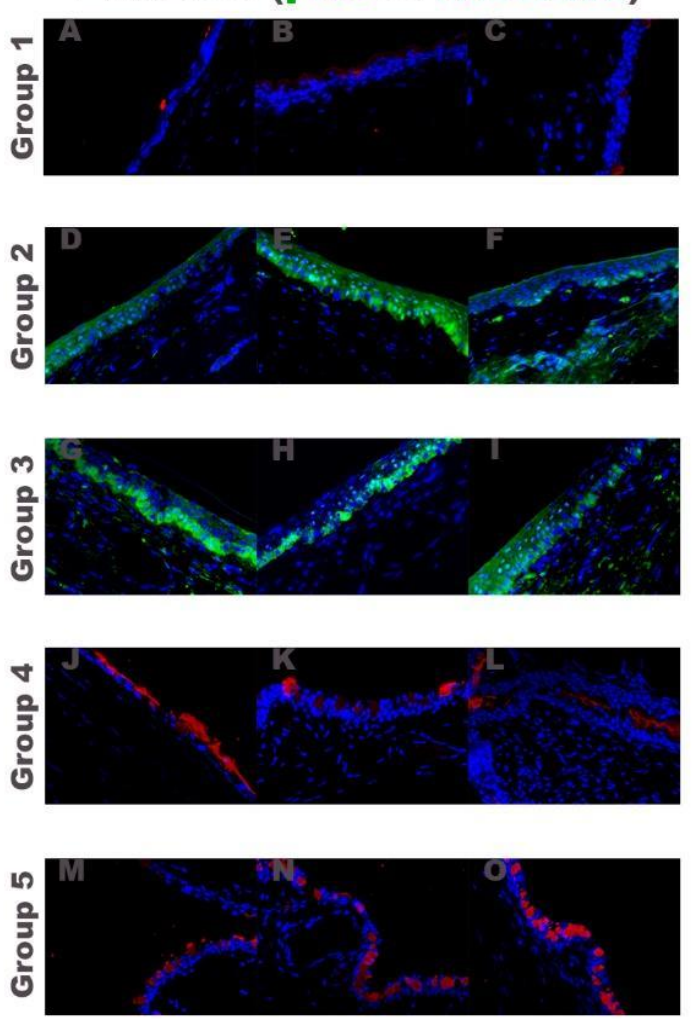

Figure 5. Immunofluorescence analysis of the limbal area with a normal limbal epithelium (p63 in green and DAPI in blue) or with a conjunctival epithelium (MUC5ac in red and DAPI in blue). Group 1: only medical treatment (control group), Group 2: fibrin-PRGF membrane cultured with autologous rabbit LEPCs, Group 3: fibrin-PRGF membrane cultured with heterologous rabbit LEPCs, Group 4: fibrin-PRGF membrane SLET and Group 5: fibrin-PRGF membrane without rabbit cultured LEPCs. 400×. PRGF: Plasma Rich in Growth Factors; LEPCs: Limbal Epithelial Progenitor Cells; SLET: Simple Limbal Epithelial Transplantation.

Moreover, in the groups of rabbits transplanted with fibrin-PRGF membrane cultured with autologous (group 2) or heterologous (group 3) rabbit LEPCs and in the group of rabbits transplanted with fibrin-PRGF membrane without rabbit cultured LEPCs (group 5), CK3 was strongly positive in the intermediate and superficial layers of the central corneal epithelium (Figure 6). In the group of rabbits treated with only medical treatment (control group) and those treated with fibrin-PRGF membrane SLET (group 4), CK7 positive conjunctival epithelium was observed both with (rabbit number three and rabbit number one, respectively) and without MUC5ac positive cells (Figure 6). 

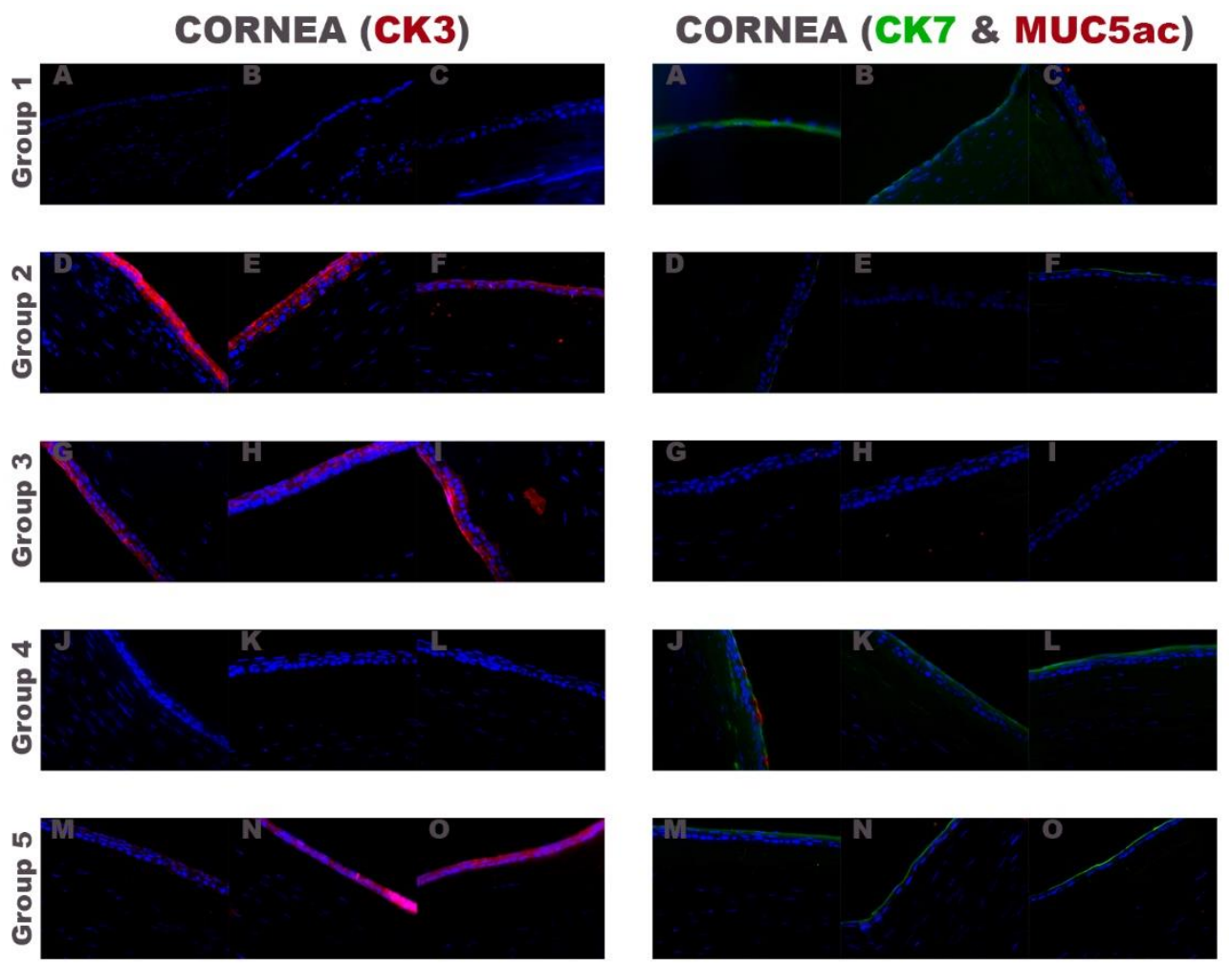

Figure 6. Immunofluorescence analysis of the central cornea with a CK3 positive (in red) multilayered corneal epithelium (left) or a CK7 positive (in green) conjunctival epithelium with or without the presence of MUC5ac positive (in red) cells (right). Group 1: only medical treatment (control group), Group 2: fibrin-PRGF membrane cultured with autologous rabbit LEPCs, Group 3: fibrin-PRGF membrane cultured with heterologous rabbit LEPCs, Group 4: fibrin-PRGF membrane SLET and Group 5: fibrin-PRGF membrane without rabbit cultured LEPCs. 400×. PRGF: Plasma Rich in Growth Factors; LEPCs: Limbal Epithelial Progenitor Cells; SLET: Simple Limbal Epithelial Transplantation.

\section{Discussion}

Ocular burns account for approximately $15 \%$ of eye events [55] and require urgent medical attention, as, if not treated early and properly, the tissues and functioning of the eye may be seriously compromised [56]. After an ocular chemical burn, interventions are aimed at decreasing the extent of the injury, suppressing inflammation, and promoting corneal re-epithelization [14].

The majority of ocular burns do not require surgical interventions, and long-term morbidity rates have been reported as low as $4.5 \%$ with medical management alone [57-59]. However, an early surgical intervention results in better patient-related outcomes and a lower risk of complications for severe ocular burn-related injury [60].

Surgical treatment of the ocular burns ranges from the application of several membranes to promote epithelization and to reduce inflammation, scarring and neovascularization, in patients with mild to moderate ocular injuries [61-63], or the use of membranes as adjuvant therapy, in patients with severe ocular injuries $[1,61,64-69]$ to the performance of penetrating keratoplasty $[70,71]$, in patients with extensive stromal scarring, or the use of keratoprosthesis, in patients who have experienced failed previous surgical procedures [72].

In this work, the efficacy of a fibrin-PRGF membrane for the surgical treatment of an alkali-burn lesion was studied in an animal model. Fibrin-PRGF membrane was used as a culture substrate because of its ability to reduce inflammation, vascularization and to stimulate the adhesion and proliferation of LEPCs $[49,50,73]$.

The first step in the treatment of the ocular chemical injury was to irrigate the ocular surface to remove the $\mathrm{NaOH}$. After that, medical treatment with antibiotics, analgesics and anti-inflammatories was administrated to prevent the infections and to reduce the 
inflammation during the acute phase (7 days). Several classification systems have been described to predict the prognosis of the lesion by grading the severity of the injury [74-76]. Since a spectrum of clinical manifestations can be described following chemical injury [5], four parameters were assessed in this study: epithelial integrity, corneal neovascularization, number of fibrovascular pannus and corneal opacity $[77,78]$.

Clinical evaluation of the rabbits showed that all of them had moderately or severely dense corneal opacity, total corneal neovascularization, fibrovascular pannus and epithelial defects seven days after the chemical lesion. A clinical diagnostic with an unfavorable prognosis, since it depends on the extent of corneal, limbal and conjunctival involvement $[4,5,7,12]$. There were no statistical differences in the scores of the different groups of treated rabbits, indicating that a similar chemical injury was performed.

In this study, the fibrin-PRGF membrane was used with different therapeutic approaches: as a graft that provides a basement membrane for epithelization (group 5), as a membrane that supports the expansion of the autologous (group 2) or heterologous (group 3) rabbit LEPCs to maximize the probability of generating a normal corneal epithelial surface, and in the SLET technique, a simple surgical technique that avoids the consideration of advanced therapy (group 4). These treatments were possible since the fibrin-PRGF membrane has demonstrated to be easily manageable in different types of surgery $[48,49]$ and to support the growth of LEPCs [50].

Rabbit LEPCs grown on fibrin-PRGF membranes were positive for the p63 marker, which has been used to determine the stem cell property of LEPCs [79] being beneficial for long-term graft survival since those cells can proliferate after transplantation.

During post-surgery healing, corneal transparency gradually improved. Within 40 days after transplantation, ocular surfaces were utterly reconstructed with clarity and smoothness, under slit-lamp microscopy, compared to those of normal cornea in the group of rabbits treated with fibrin-PRGF membrane cultured with autologous (group 2) or heterologous (group 3) rabbit LEPCs and in the group of rabbits treated with fibrin-PRGF membrane without cultured LEPCs (group 5). In the groups of rabbits treated only with medical treatment (control group) and rabbits transplanted with fibrin-PRGF membrane SLET (group 4), epithelial defects were detected by slit-lamp examination. One rabbit in the group of fibrin-PRGF membrane cultured with autologous LEPCs showed a corneal edema, which could be explained by the absence of corneal endothelium in a cornea area (data are not shown).

Following clinical observations, the cornea was covered by stratified epithelium displaying corneal phenotype (positive CK3), and the limbal epithelium resembled a normal appearance with limbal stem cells identified by $\mathrm{p} 63$ positive labeling in the groups of rabbits treated with fibrin-PRGF membrane cultured with autologous (group 2) or heterologous (group 3) rabbit LEPCs. In contrast, in the other three groups (groups 1, 4, and 5), goblet cells were observed in the limbal epithelium, indicating conjunctivalization into the limbal area. These results seem to indicate that the fibrin-PRGF membrane has a beneficial effect after alkali-burn injury, but it is not able to restore the correct function of a normal cornea by itself $[80,81]$.

In accordance with other studies [82,83], our results showed that a heterologous limbal transplant was as effective as an autologous limbal transplant in treating the alkali-burn lesion. Restoring the ocular surface using expanded heterologous LEPCs represents an encouraging milestone since it would allow the treatment of alkali-burn injuries without compromising the contralateral healthy eye.

Another therapeutic approach, such as the SLET technique, is an even more promising treatment option since it is an easy procedure that does not require in vitro cell culture techniques. Previous studies have shown satisfactory results using this technique $[38,40,84,85]$. However, in this study, the results obtained have not been satisfactory. These results could be explained because the tarsorrhaphy was opened seven days after the treatment, possibly an inadequate time for integrating the explant onto the ocular surface and to establish 
a complete corneal epithelium. Better clinical results could have been obtained with a different experimental design.

In the last years, several in vivo studies and clinical trials have demonstrated that fibrin membranes are a suitable scaffold for the culture and transplant of LEPCs, leading in 2015 to the approval of Holoclar ${ }^{\circledR}$ by the European Medicines Agency (EMA), the first Advanced Therapy Medicinal Product (ATMP) containing limbal stem cells in a fibrin scaffold for the treatment of a moderate or severe chemical-induced LSCD [86]. On the other hand, several effective xeno-free techniques of limbal cultivation have been reported to treat chemical ocular lesions $[87,88]$. However, Holoclar ${ }^{\circledR}$ therapy includes the use of feeder mouse cells and bovine serum, so it is contraindicated for patients with a hyper sensibility to xenogeneic proteins [46], and in most of the xeno-free techniques, an amniotic membrane is used to expand LEPCs, which has some remarkable disadvantages due to the allogeneic origin, the potential pathogen transmission, and high manufacturing costs [89].

In this study, the use of feeder mouse cells was avoided, and limbal explants were used for the expansion of rabbit LEPCs in a simple technique of cellular culture. Although a complete medium with SBF, cholera toxin, among other supplements were used for the expansion of rabbit LEPCs, which was the major limitation of this study, this fact could be modified in the translation of our results to the clinical practice, since human LEPC s have been satisfactorily cultured on a fibrin-PRGF membrane using PRGF as the unique supplement of the culture medium [50]. Thus, a therapy could be developed in which PRGF obtained from patient's blood could be used for the culture of LEPCs on a fibrin-PRGF membrane for the treatment of patients with severe chemical injuries or a fibrin-PRGF membrane could also be suitable in cases of less severe chemical ocular lesion.

\section{Materials and Methods}

\subsection{Experimental Design}

Fifteen healthy male New Zealand white rabbits ( 2 months of age and body weight of $2.0-2.5 \mathrm{~kg}$ ) obtained from the Animal Housing Facility of the University of Oviedo (Oviedo, Asturias, Spain) were used in this work. All animals were treated in accordance with the ARVO Statement to use animals in ophthalmic and vision research and EU Directive 2010/63/EU for animal experiment. The protocols were approved (PROAE 33/2016) by the Committee on the Ethics of Animal Experiments of the University of Oviedo and the Animal Production and Health Service of Asturias. Rabbits were kept under a 12/12 day/night light cycle with food and water ad libitum and were monitored daily.

An alkali-burn lesion was induced in all rabbits, and a week later, all rabbits were clinically examined and treated. Animals were randomly divided into five groups of three rabbits each: rabbits treated only with medical treatment (group 1: control group), rabbits treated with a fibrin-PRGF membrane cultured with autologous (group 2) or heterologous (group 3) rabbit LEPCs, rabbits treated with fibrin-PRGF membrane SLET (group 4) and rabbits treated with a fibrin-PRGF membrane without rabbit cultured LEPCs (group 5). Once a week, rabbits were evaluated (epithelial integrity, corneal neovascularization, fibrovascular pannus and corneal opacity), and after 40 days of clinical follow-up, all rabbits were euthanized, and excised corneas were subjected to histochemical examination.

\subsection{Cell Culture}

Small limbal biopsies $(1 \times 2 \mathrm{~mm})$ were excised from the limbus of the rabbits' right eye before the performance of alkali-burn lesion (groups 2 and 3). Limbal biopsies were stored in Leibovitz's (Thermo Fisher Scientific, Waltham, MA, USA) supplemented with $100 \mathrm{U} / \mathrm{mL}$ penicillin and $0.1 \mathrm{mg} / \mathrm{mL}$ streptomycin (Sigma-Aldrich, Saint Louis, MO, USA) until culture.

For culture procedure, limbal biopsies were cut into small pieces and cultured for five days on a 12-well culture plate in a 2:1 mixture of Dulbecco's modified Eagle's medium (DMEM, Thermo Fisher Scientific) and Ham's F12 (Thermo Fisher Scientific), supplemented 
with $5 \mu \mathrm{g} / \mathrm{mL}$ insulin, $8.33 \mathrm{ng} / \mathrm{mL}$ cholera toxin, $24 \mu \mathrm{g} / \mathrm{mL}$ adenine, $1.3 \mathrm{ng} / \mathrm{mL}$ triiodothyronine, $0.4 \mu \mathrm{g} / \mathrm{mL}$ hydrocortisone, $10 v / v \%$ fetal bovine serum (FBS) and $100 \mathrm{U} / \mathrm{mL}$ penicillin, $0.1 \mathrm{mg} / \mathrm{mL}$ streptomycin (Sigma-Aldrich). After five days of culture, rabbit LEPCs were trypsinized, counted in a hemocytometer and subcultured on a fibrin-PRGF membrane for $48 \mathrm{~h}$ (groups 2 and 3 ).

Rabbit fibrin-PRGF membranes were obtained from rabbit blood samples and were processed according to the methodology described by Anitua et al. [90]. Briefly, for each membrane, $5 \mathrm{~mL}$ of recovered plasma were incubated in the presence of $250 \mu \mathrm{L}$ of $10 \%$ $\mathrm{CaCl}_{2}$ in a $35 \mathrm{~mm}$ diameter dish at $37^{\circ} \mathrm{C}$ for $30 \mathrm{~min}$. Once a gel was formed, fibrin-PRGF membranes were obtained by flattening for $30 \mathrm{~s}$ using a $500 \mu \mathrm{m}$ fibrin membrane shaper (BTI, Vitoria, País Vasco, Spain).

All cultures were maintained in a humidified incubator at $37^{\circ} \mathrm{C}$ with $5 \% \mathrm{CO}_{2}$, and the medium was changed every two days.

Cellular growth was assessed using a Leica DMIL LED phase-contrast microscope (Leica, Wetzlar, Hesse, Germany), and photos were taken with an attached EC3 camera (Leica). Moreover, fibrin-PRGF membranes cultured with rabbit LEPCs were fixed in ice-cold methanol (Sigma-Aldrich) for $10 \mathrm{~min}$ for histological analysis.

\subsection{Rabbit Alkali-Burn Model}

New Zealand white rabbits were treated with Bupaq ${ }^{\circledR}(0.01-0.05 \mathrm{mg} / \mathrm{kg}$ buprenorphine, Richter Pharma, Wells, Austria) and Metacam ${ }^{\circledR}(0.3 \mathrm{mg} / \mathrm{kg}$ meloxicam, Boehringer Ingelheim, Ingelheim am Rhein, Germany), and then were intubated and ventilated with isoflurane 2\% (Ecuphar Veterinaria, Barcelona, Cataluña, Spain). After topical administration of double anesthetic Colicursi ${ }^{\circledR}(0.1 \%$ tetracaine and $0.4 \%$ oxybuprocaine, Alcon, Geneva, Switzerland), the alkali-burn lesion was performed by applying a gauze soaked in $1 \mathrm{M} \mathrm{NaOH}$ (VWR, Radnor, Pennsylvania, USA) on the right eye (left eye served as healthy control) for $10 \mathrm{~s}$. After that, eyes were rinsed with balanced salt solution (Alcon); the central epithelium was removed with eye spears and Tobrex ${ }^{\circledR}(3 \mathrm{mg} / \mathrm{mL}$ tobramycin, Alcon) and Cetraflux ${ }^{\circledR}$ (3 mg/mL ciprofloxacin, Salvat, Barcelona, cataluña, Spain) eye drops were administered before performing a tarsorrhaphy with $4-0$ silk suture (Ethicon, Bridgewater, NJ, USA). Once a day, rabbits received subdermal injections of Metacam ${ }^{\circledR}$, Bupaq $^{\circledR}$ and $\operatorname{Alsir}^{\circledR}$ (5 mg/kg enrofloxacin, Esteve, Barcelona, Cataluña, Spain) until treatment.

\subsection{Clinical Evaluation and Surgical Procedures}

Seven days after the alkali-burn lesion, the ocular surface was photographed and evaluated by slit-lamp (Kowa, Dusseldorf, North Rhine-Westphalia, Germany), and the extent of epithelial damage was assessed by fluorescein stain. Opacification, neovascularization, number of fibrovascular pannus and epithelial defects observed in the photographs were evaluated according to the criteria shown in Table $4[77,78]$.

Table 4. Scores for clinical evaluation.

\begin{tabular}{cccccc}
\hline & Score 0 & Score 1 & Score 2 & Score 3 & Score 4 \\
\hline Corneal Opacification & Totally clear & Haze of minimal density & Mild haze & Moderately dense opacity & Severely dense opacity \\
Corneal & No vessels & $<1 / 4$ & $>1 / 4$ and $<1 / 2$ & $>1 / 2$ and $<3 / 4$ & $>3 / 4$ \\
Neovascularization & 0 & 1 & 2 & 3 & $>4$ \\
Fibrovascular Pannus & No fluorescein stain & $<1 / 4$ & $>1 / 4$ and $<1 / 2$ & $>1 / 2$ and $<3 / 4$ & $>3 / 4$ \\
Epithelial Defects & No & &
\end{tabular}

Once the rabbits were evaluated, they were anesthetized according to the procedure described above, and the different treatments were carried out. For this purpose, intracorneal vessels were removed, and a fibrin-PRGF membrane was sutured with autologous (group 2), heterologous (group 3) or without rabbit cultured LEPCs (group 5) with cells facing the cornea. In the case of rabbits transplanted with fibrin-PRGF membrane SLET (group 4), a $2 \mathrm{~mm}$ limbal biopsy of the contralateral eye was taken, cut into 10 pieces, and 
glued with Tisseel ${ }^{\circledR}$ (Baxter, Glenview, IL, USA) over a fibrin-PRGF membrane. Then, a second fibrin-PRGF membrane was sutured over the explants with 8-0 absorbable suture (Vicryl ${ }^{\circledR}$, Ethicon).

All rabbits received Vigamox ${ }^{\circledR}(5 \mathrm{mg} / \mathrm{mL}$ moxifloxacin, Alcon $)$ and Dexafree ${ }^{\circledR}$ ( $1 \mathrm{mg} / \mathrm{mL}$ dexamethasone phosphate, Théa, Barcelona, Cataluña, Spain) eye drops and one subconjunctival injection of Celestone ${ }^{\circledR}(3 \mathrm{mg} / \mathrm{mL}$ betamethasone, Schering-Plough, Kenilworth, NJ, USA) before performing a tarsorrhaphy with 4-0 silk suture. Once a day, rabbits received subdermal injections of Metacam ${ }^{\circledR}$, Bupaq ${ }^{\circledR}$ and Alsir ${ }^{\circledR} 5 \%$ for seven days. Tarsorrhaphy was opened after seven days, and rabbits were treated with Vigamox ${ }^{\circledR}$, and Dexafree ${ }^{\circledR}$ eye drops twice a day during the follow-up period. The rabbits in group 1 (control group) received only medical treatment.

\subsection{Clinical Outcome Analysis}

Rabbits' eyes were monitored with slit-lamp examination, fluorescein staining and photography once a week during the 40 days of the follow-up period. Epithelial integrity, corneal neovascularization, fibrovascular pannus and corneal opacity were evaluated and scored by the same examiner in a masked fashion following the previously described criteria (Table 4).

\subsection{Histology and Immunocytochemistry}

After the follow-up period, rabbits were euthanized by an intravenous overdose of pentobarbital sodium (Vetoquinol, Madrid, Spain) and corneas were excised, rinsed in PBS solution, and fixed in ice-cold methanol for $24 \mathrm{~h}$ for histological analysis. Fixed fibrin-PRGF membranes cultured with rabbit LEPCs and rabbit corneas were embedded in paraffin (Thermo Fisher Scientific), and $3 \mu \mathrm{m}$ sections were cut with a microtome (Leica), placed on commercially treated slides (Thermo Fisher Scientific) and stained with hematoxylineosin (Sigma-Aldrich). Immunostaining of the corneal sections using antibody against cytokeratin 3 (CK 3) (1:100; Catalog number: ab68260, Abcam, Cambridge, UK) was used to identify differentiated corneal epithelial cells and antibodies against MUC5ac (1:100; Catalog number: ab212636, Abcam) and cytokeratin 7 (CK 7) (1:100; Catalog number: ab181598, Abcam) were used to identify goblet cells and conjunctival epithelial cells, respectively. Moreover, the antibody against p63 (1:100; Catalog number: ab124762, Abcam) was used to identify progenitor limbal stem cells in fibrin-PRGF membranes cultured with rabbit LEPCs and rabbit corneas. Briefly, samples were deparaffinized, hydrated and rinsed with PBS solution twice for $10 \mathrm{~min}$ and permeabilized in a PBS solution containing $0.3 \%$ Triton X-100 (VWR, Radnor, PA, USA) for another $10 \mathrm{~min}$. Next, the samples were incubated with primary antibodies containing 10\% normal goat serum (Catalog number: ab7481, Abcam, Cambridge, UK) at $4{ }^{\circ} \mathrm{C}$ overnight. Subsequently, the samples were incubated with the corresponding secondary antibody (1:500; Catalog number: A-11032 and A-11034, Thermo Fisher Scientific) for $2 \mathrm{~h}$ at room temperature. Between incubations, samples were washed three times with PBS for $10 \mathrm{~min}$. Immunolabeled cells were stained with 4', 6-diamidino-2-phenylindole (DAPI) to allow nuclei visualization. All the samples were examined in a Leica DM6000B fluorescence microscope (Leica), and photographs were taken in the central cornea, peripheral cornea and limbus, identified as the first area where stromal vascular vessels were observed.

\subsection{Statistical Analysis}

Statistical analysis was performed using IBM SPSS Statistics v.22 software (IBM, Armonk, NY, USA). The mean, standard deviation and percentages were used for descriptive analysis. The Wilcoxon test was used to compare the clinical evaluations between the beginning and end of the follow-up period and the Kruskal-Wallis test to compare the results between the groups. A level of $p<0.05$ was considered statistically significant. 


\section{Conclusions}

Fibrin-PRGF membranes improved chemically induced lesions in a rabbit alkali-burn model but only fibrin-PRGF membranes with autologous or heterologous cultured rabbit LEPCs were able to restore the corneal surface. SLET technique with a fibrin-PRGF membrane did not show satisfactory results in this study. Additional data should be collected with a larger sample size, at a longer follow-up and with a different experimental design.

Author Contributions: Conceptualization, Á.M. and J.M.-L.; methodology, R.M.S.-Á., N.V., M.C. and Á.M.; software, R.M.S.-Á.; formal analysis, R.M.S.-Á., N.V. and Á.M.; investigation, R.M.S.-Á., N.V., A.B.-P. and M.P.-M.; resources, S.B.-P., L.F.-V.-C., E.A., Á.M. and J.M.-L.; data curation, R.M.S.-Á., N.V. and M.C.; writing—original draft preparation, R.M.S.-Á., N.V. and Á.M.; writing—review and editing, R.M.S.-Á., N.V., M.C., M.P.-M., A.B.-P., S.B.-P.; L.F.-V.-C., E.A., Á.M. and J.M.-L.; supervision, Á.M. and J.M.-L.; funding acquisition, L.F.-V.-C., E.A., Á.M. and J.M.-L. All authors have read and agreed to the published version of the manuscript.

Funding: This research was funded in part by grant FC-15-GRUPIN14-141 (Government of Principado de Asturias cofinanced by European Regional Development Fund (FEDER)) and by Fundación Telefónica, Spain.

Institutional Review Board Statement: All animals were treated in accordance with the ARVO Statement to use animals in ophthalmic and vision research and EU Directive 2010/63/EU for animal experiment. The protocols were approved (PROAE 33/2016) by the Committee on the Ethics of Animal Experiments of the University of Oviedo and the Animal Production and Health Service of Asturias.

Data Availability Statement: All the obtained data used to support the findings of this study are available from the corresponding author upon reasonable request.

Acknowledgments: The authors wish to thank Centro Comunitario de Sangre y Tejidos de Asturias for their assistance during the experiments. The authors thank Virginia Cuadrado for her support with the English grammar.

Conflicts of Interest: The authors declare the following competing financial interest(s): E.A. is the Scientific Director of Biotechnology Institute (BTI) and R.M.S.-Á. is a scientific at Biotechnology Institute (BTI). The other authors declare no conflicts of interest in developing this study.

$\begin{array}{ll}\text { Abbreviations } \\ \text { PRGF } & \text { Plasma Rich in Growth Factors } \\ \text { LEPCs } & \text { Limbal Epithelial Progenitor Cells } \\ \text { SLET } & \text { Simple Limbal Epithelial Transplantation } \\ \text { LSCD } & \text { Limbal Stem Cell Deficiency } \\ \text { DMEM } & \text { Dulbecco's modified Eagle's medium } \\ \text { FBS } & \text { fetal bovine serum } \\ \text { CK } & \text { cytokeratin } \\ \text { PBS } & \text { phosphate buffered saline } \\ \text { DAPI } & 4^{\prime}, 6 \text {-diamidino-2-phenylindole } \\ \text { EMA } & \text { European Medicines Agency } \\ \text { ATMP } & \text { Advanced Therapy Medicinal Product }\end{array}$

\section{References}

1. Fish, R.; Davidson, R.S. Management of ocular thermal and chemical injuries, including amniotic membrane therapy. Curr. Opin. Ophthalmol. 2010, 21, 317-321. [CrossRef] [PubMed]

2. Singh, P.; Tyagi, M.; Kumar, Y.; Gupta, K.; Sharma, P. Ocular chemical injuries and their management. Oman J. Ophthalmol. 2013, 6, 83-86. [CrossRef] [PubMed]

3. Sharma, N.; Kaur, M.; Agarwal, T.; Sangwan, V.S.; Vajpayee, R.B. Treatment of acute ocular chemical burns. Surv. Ophthalmol. 2018, 63, 214-235. [CrossRef] [PubMed]

4. Cabalag, M.S.; Wasiak, J.; Syed, Q.; Paul, E.; Hall, A.J.; Cleland, H. Early and late complications of ocular burn injuries. J. Plast. Reconstr. Aesthetic Surg. 2015, 68, 356-361. [CrossRef] 
5. Eslani, M.; Baradaran-Rafii, A.; Movahedan, A.; Djalilian, A.R. The ocular surface chemical burns. J. Ophthalmol. $2014,2014$. [CrossRef]

6. Kuckelkorn, R.; Kottek, A.; Schrage, N.; Reim, M. Poor prognosis of severe chemical and thermal eye burns: The need for adequate emergency care and primary prevention. Int. Arch. Occup. Environ. Health 1995, 67, 281-284. [CrossRef]

7. Pfister, R.R. Chemical Corneal Burns. Int. Ophthalmol. Clin. 1984, 24, 157-168.

8. Wagoner, M.D. Chemical injuries of the eye: Current concepts in pathophysiology and therapy. Surv. Ophthalmol. 1997, 41, 275-313. [CrossRef]

9. Bunker, D.J.L.; George, R.J.; Kleinschmidt, A.; Kumar, R.J.; Maitz, P. Alkali-related ocular burns: A case series and review. J. Burn Care Res. 2014, 35, 261-268. [CrossRef]

10. Moreno-Arrones, J.; Merayo-Lloves, J.; Varilla, D. Ocular chemical burns in the workplace: Epidemiological characteristics. Burns 2020, 46, 1212-1218. [CrossRef]

11. Lin, A.; Patel, N.; Yoo, D.; Demartelaere, S.; Bouchard, C. Management of ocular conditions in the burn unit: Thermal and chemical burns and stevens-johnson syndrome/toxic epidermal necrolysis. J. Burn Care Res. 2011, 32, 547-560. [CrossRef] [PubMed]

12. Schrage, N.F.; Langefeld, S.; Zschocke, J.; Kuckelkorn, R.; Redbrake, C.; Reim, M. Eye burns: An emergency and continuing problem. Burns 2000, 26, 689-699. [CrossRef]

13. Spector, J.; Fernandez, W.G. Chemical, Thermal, and Biological Ocular Exposures. Emerg. Med. Clin. N. Am. 2008, 26, 125-136. [CrossRef] [PubMed]

14. Baradaran-Rafii, A.; Eslani, M.; Haq, Z.; Shirzadeh, E.; Huvard, M.J.; Djalilian, A.R. Current and Upcoming Therapies for Ocular Surface Chemical Injuries. Ocul. Surf. 2017, 15, 48-64. [CrossRef] [PubMed]

15. Hamill, C.E.; Bozorg, S.; Peggy Chang, H.Y.; Lee, H.; Sayegh, R.R.; Shukla, A.N.; Chodosh, J. Corneal alkali burns: A review of the literature and proposed protocol for evaluation and treatment. Int. Ophthalmol. Clin. 2013, 53, 185-194. [CrossRef] [PubMed]

16. McCulley, J. Chemical injuries. In The Cornea: Scientific Foundation and Clinical Practice; Smolin, G., Thoft, R.A., Eds.; Little, Brown and Co.: Boston, MA, USA, 1987; pp. 527-542.

17. Cotsarelis, G.; Cheng, S.Z.; Dong, G.; Sun, T.T.; Lavker, R.M. Existence of slow-cycling limbal epithelial basal cells that can be preferentially stimulated to proliferate: Implications on epithelial stem cells. Cell 1989, 57, 201-209. [CrossRef]

18. Davanger, M.; Evensen, A. Role of the pericorneal papillary structure in renewal of corneal epithelium. Nature 1971, $229,560-561$. [CrossRef] [PubMed]

19. Ordonez, P.; Di Girolamo, N. Concise review: Limbal epithelial stem cells: Role of the niche microenvironment. Stem Cells 2012, 30, 100-107. [CrossRef]

20. Sangwan, V.S. Limbal stem cells in health and disease. Biosci. Rep. 2001, 21, 385-405. [CrossRef]

21. Schermer, A.; Galvin, S.; Sun, T.T. Differentiation-related expression of a major 64K corneal keratin in vivo and in culture suggests limbal location of corneal epithelial stem cells. J. Cell Biol. 1986, 103, 49-62. [CrossRef]

22. Van Buskirk, E.M. The anatomy of the limbus. Eye 1989, 3, 101-108. [CrossRef] [PubMed]

23. Tseng, S.C. Concept and application of limbal stem cells. Eye 1989, 3, 141-157. [CrossRef] [PubMed]

24. Dua, H.S.; Gomes, J.A.P.; Singh, A. Corneal epithelial wound healing. Br. J. Ophthalmol. 1994, 78, 401-408. [CrossRef] [PubMed]

25. Ahmad, S. Concise Review: Limbal Stem Cell Deficiency, Dysfunction, and Distress. Stem Cells Transl. Med. 2012, 1, 110-115. [CrossRef] [PubMed]

26. Anderson, D.F.; Ellies, P.; Pires, R.T.F.; Tseng, S.C.G. Amniotic membrane transplantation for partial limbal stem cell deficiency. Br. J. Ophthalmol. 2001, 85, 567-575. [CrossRef] [PubMed]

27. Kenyon, K.R.; Tseng, S.C.G. Limbal Autograft Transplantation for Ocular Surface Disorders. Ophthalmology 1989, 96, 709-723. [CrossRef]

28. Titiyal, J.S.; Sharma, N.; Agarwal, A.K.; Prakash, G.; Tandon, R.; Vajpayee, R. Live related versus cadaveric limbal allograft in limbal stem cell deficiency. Ocul. Immunol. Inflamm. 2015, 23, 232-239. [CrossRef]

29. Welder, J.D.; Pandya, H.K.; Nassiri, N.; Djalilian, A.R. Conjunctival limbal autograft and allograft transplantation using fibrin glue. Ophthalmic Surg. Lasers Imaging 2012, 43, 323-327. [CrossRef]

30. Pellegrini, G.; Traverso, C.E.; Franzi, A.T.; Zingirian, M.; Cancedda, R.; De Luca, M. Long-term restoration of damaged corneal surfaces with autologous cultivated corneal epithelium. Lancet 1997, 349, 990-993. [CrossRef]

31. Nakamura, T.; Inatomi, T.; Sotozono, C.; Amemiya, T.; Kanamura, N.; Kinoshita, S. Transplantation of cultivated autologous oral mucosal epithelial cells in patients with severe ocular surface disorders. Br. J. Ophthalmol. 2004, 88, 1280-1284. [CrossRef]

32. Nakamura, T.; Takeda, K.; Inatomi, T.; Sotozono, C.; Kinoshita, S. Long-term results of autologous cultivated oral mucosal epithelial transplantation in the scar phase of severe ocular surface disorders. Br. J. Ophthalmol. 2011, 95, 942-946. [CrossRef] [PubMed]

33. Rama, P.; Bonini, S.; Lambiase, A.; Golisano, O.; Paterna, P.; De Luca, M.; Pellegrini, G. Autologous fibrin-cultured limbal stem cells permanently restore the corneal surface of patients with total limbal stem cell deficiency. Transplantation 2001, 72, 1478-1485. [CrossRef]

34. Calonge, M.; Pérez, I.; Galindo, S.; Nieto-Miguel, T.; López-Paniagua, M.; Fernández, I.; Alberca, M.; García-Sancho, J.; Sánchez, A.; Herreras, J.M. A proof-of-concept clinical trial using mesenchymal stem cells for the treatment of corneal epithelial stem cell deficiency. Transl. Res. 2019, 206, 18-40. [CrossRef] [PubMed] 
35. Holan, V.; Trosan, P.; Cejka, C.; Javorkova, E.; Zajicova, A.; Hermankova, B.; Chudickova, M.; Cejkova, J. A Comparative Study of the Therapeutic Potential of Mesenchymal Stem Cells and Limbal Epithelial Stem Cells for Ocular Surface Reconstruction. Stem Cells Transl. Med. 2015, 4, 1052-1063. [CrossRef] [PubMed]

36. Sangwan, V.S.; Basu, S.; MacNeil, S.; Balasubramanian, D. Simple limbal epithelial transplantation (SLET): A novel surgical technique for the treatment of unilateral limbal stem cell deficiency. Br. J. Ophthalmol. 2012, 96, 931-934. [CrossRef] [PubMed]

37. Bhalekar, S.; Basu, S.; Sangwan, V.S. Successful management of immunological rejection following allogeneic simple limbal epithelial transplantation (SLET) for bilateral ocular burns. BMJ Case Rep. 2013, 2013. [CrossRef]

38. Basu, S.; Sureka, S.P.; Shanbhag, S.S.; Kethiri, A.R.; Singh, V.; Sangwan, V.S. Simple Limbal Epithelial Transplantation: Long-Term Clinical Outcomes in 125 Cases of Unilateral Chronic Ocular Surface Burns. Ophthalmology 2016, 123, 1000-1010. [CrossRef]

39. Vazirani, J.; Ali, M.H.; Sharma, N.; Gupta, N.; Mittal, V.; Atallah, M.; Amescua, G.; Chowdhury, T.; Abdala-Figuerola, A.; RamirezMiranda, A.; et al. Autologous simple limbal epithelial transplantation for unilateral limbal stem cell deficiency: Multicentre results. Br. J. Ophthalmol. 2016, 100, 1416-1420. [CrossRef]

40. Amescua, G.; Atallah, M.; Nikpoor, N.; Galor, A.; Perez, V.L. Modified Simple Limbal Epithelial Transplantation Using Cryopreserved Amniotic Membrane for Unilateral Limbal Stem Cell Deficiency. Am. J. Ophthalmol. 2014, 158, 469-475. [CrossRef]

41. Mahdavi, S.S.; Abdekhodaie, M.J.; Mashayekhan, S.; Baradaran-Rafii, A.; Djalilian, A.R. Bioengineering Approaches for Corneal Regenerative Medicine. Tissue Eng. Regen. Med. 2020, 17, 567-593. [CrossRef]

42. Gouveia, R.M.; Connon, C.J. Biomechanical modulation therapy-A stem cell therapy without stem cells for the treatment of severe ocular burns. Transl. Vis. Sci. Technol. 2020, 9, 1-11. [CrossRef]

43. Brown, K.D.; Low, S.; Mariappan, I.; Abberton, K.M.; Short, R.; Zhang, H.; Maddileti, S.; Sangwan, V.; Steele, D.; Daniell, M. Plasma polymer-coated contact lenses for the culture and transfer of corneal epithelial cells in the treatment of limbal stem cell deficiency. Tissue Eng. Part A 2014, 20, 646-655. [CrossRef] [PubMed]

44. Levis, H.J.; Peh, G.S.L.; Toh, K.-P.; Poh, R.; Shortt, A.J.; Drake, R.A.L.; Mehta, J.S.; Daniels, J.T. Plastic Compressed Collagen as a Novel Carrier for Expanded Human Corneal Endothelial Cells for Transplantation. PLoS ONE 2012, 7, e50993. [CrossRef] [PubMed]

45. Ramachandran, C.; Sangwan, V.S.; Ortega, I.; Bhatnagar, U.; Mulla, S.M.A.; McKean, R.; MacNeil, S. Synthetic biodegradable alternatives to the use of the amniotic membrane for corneal regeneration: Assessment of local and systemic toxicity in rabbits. Br. J. Ophthalmol. 2019, 103, 286-292. [CrossRef]

46. Can, G.D.; Akdere, Ö.E.; Can, M.E.; Aydın, B.; Cagil, N.; Gümüşderelioğlu, M. A completely human-derived biomaterial mimicking limbal niche: Platelet-rich fibrin gel. Exp. Eye Res. 2018, 173, 1-12. [CrossRef]

47. Anitua, E.; Zalduendo, M.M.; Alkhraisat, M.H.; Orive, G. Release kinetics of platelet-derived and plasma-derived growth factors from autologous plasma rich in growth factors. Ann. Anat. 2013, 195, 461-466. [CrossRef] [PubMed]

48. Sanchez-Avila, R.M.; Merayo-Lloves, J.; Riestra, A.C.; Berisa, S.; Lisa, C.; Sánchez, J.A.; Muruzabal, F.; Orive, G.; Anitua, E. Plasma rich in growth factors membrane as coadjuvant treatment in the surgery of ocular surface disorders. Medicine 2018, 97, e0242. [CrossRef] [PubMed]

49. Sabater, A.L.; Mousa, H.M.; Quinones, X.; Valenzuela, F.; Sanchez Avila, R.M.; Orive, G.; Anitua, E.; Merayo, J.; Perez, V.L. Use of autologous plasma rich in growth factors fibrin membrane in the surgical management of ocular surface diseases. Int. Ophthalmol. 2021. [CrossRef] [PubMed]

50. Riestra, A.C.; Vazquez, N.; Chacon, M.; Berisa, S.; Sanchez-Avila, R.M.; Orive, G.; Anitua, E.; Meana, A.; Merayo-Lloves, J. Autologous method for ex vivo expansion of human limbal epithelial progenitor cells based on plasma rich in growth factors technology. Ocul. Surf. 2017, 15, 248-256. [CrossRef] [PubMed]

51. Bennardo, F.; Bennardo, L.; Del Duca, E.; Patruno, C.; Fortunato, L.; Giudice, A.; Nisticò, S.P. Autologous platelet-rich fibrin injections in the management of facial cutaneous sinus tracts secondary to medication-related osteonecrosis of the jaw. Dermatol. Ther. 2020, 33, e13334. [CrossRef]

52. Bennardo, F.; Liborio, F.; Barone, S.; Antonelli, A.; Buffone, C.; Fortunato, L.; Giudice, A. Efficacy of platelet-rich fibrin compared with triamcinolone acetonide as injective therapy in the treatment of symptomatic oral lichen planus: A pilot study. Clin. Oral Investig. 2021, 1-9. [CrossRef]

53. Pachito, D.V.; Bagattini, A.M.; de Almeida, A.M.; Mendrone-Júnior, A.; Riera, R. Technical Procedures for Preparation and Administration of Platelet-Rich Plasma and Related Products: A Scoping Review. Front. Cell Dev. Biol. 2020, 8, 598816. [CrossRef]

54. Everts, P.; Onishi, K.; Jayaram, P.; Lana, J.F.; Mautner, K. Platelet-rich plasma: New performance understandings and therapeutic considerations in 2020. Int. J. Mol. Sci. 2020, 21, 7794. [CrossRef] [PubMed]

55. Del Río Fernández, S.; Gutiérrez Díaz, E.; Mencía Gutiérrez, E.; Gutiérrez Díaz, A. Traumatismos oculares. In Atlas Urgencias en Oftalmología; Bengoa, Á., Gutiérrez, E., Pérez, E., Eds.; Glosa: Barcelona, Spain, 2009; Volume 1, pp. 19-26. ISBN 84-7429-161-5.

56. Bonilla-Escobar, F.J.; Espandar, L.; Puyana, J.C. Chemical ocular burn epidemiology-dealing with missing values. JAMA Ophthalmol. 2017, 135, 892-893. [CrossRef] [PubMed]

57. Cabalag, M.S.; Wasiak, J.; Syed, Q.; Paul, E.; Hall, A.J.; Cleland, H. Risk Factors for Ocular Burn Injuries Requiring Surgery. J. Burn Care Res. 2017, 38, 71-77. [CrossRef] [PubMed]

58. Smith, S.B.; Coffee, T.; Yowler, C.; Steinemann, T.L. Risk factors for ophthalmic complications in patients with burns. J. Burn Care Res. 2010, 31, 911-917. [CrossRef] [PubMed] 
59. Spencer, T.; Hall, A.J.H.; Stawell, R.J. Ophthalmologic sequelae of thermal burns over ten years at the Alfred Hospital. Ophthal. Plast. Reconstr. Surg. 2002, 18, 196-201. [CrossRef]

60. Klifto, K.M.; Elhelali, A.; Gurno, C.F.; Seal, S.M.; Asif, M.; Hultman, C.S. Acute surgical vs non-surgical management for ocular and peri-ocular burns: A systematic review and meta-analysis. Burn. Trauma 2019, 7, 25. [CrossRef]

61. Bouchard, C.S.; John, T. Amniotic membrane transplantation in the management of severe ocular surface disease: Indications and outcomes. Ocul. Surf. 2004, 2, 201-211. [CrossRef]

62. Dua, H.S.; Gomes, J.A.P.; King, A.J.; Maharajan, V.S. The amniotic membrane in ophthalmology. Surv. Ophthalmol. 2004, 49 , 51-77. [CrossRef]

63. Tseng, S.C.; Espana, E.M.; Kawakita, T.; Di Pascuale, M.A.; Li, W.; He, H.; Liu, T.S.; Cho, T.H.; Gao, Y.Y.; Yeh, L.K.; et al. How does amniotic membrane work? Ocul. Surf. 2004, 2, 177-187. [CrossRef]

64. Azuara-Blanco, A.; Pillai, C.T.; Dua, H.S. Amniotic membrane transplantation for ocular surface reconstruction. Br. J. Ophthalmol. 1999, 83, 399-402. [CrossRef]

65. Baradaran-Rafii, A.; Javadi, M.A.; Rezaei Kanavi, M.; Eslani, M.; Jamali, H.; Karimian, F. Limbal Stem Cell Deficiency in Chronic and Delayed-onset Mustard Gas Keratopathy. Ophthalmology 2010, 117, 246-252. [CrossRef] [PubMed]

66. Fernandes, M.; Sridhar, M.S.; Sangwan, V.S.; Rao, G.N. Amniotic membrane transplantation for ocular surface reconstruction. Cornea 2005, 24, 643-653. [CrossRef] [PubMed]

67. Kheirkhah, A.; Johnson, D.A.; Paranjpe, D.R.; Raju, V.K.; Casas, V.; Tseng, S.C.G. Temporary sutureless amniotic membrane patch for acute alkaline burns. Arch. Ophthalmol. 2008, 126, 1059-1066. [CrossRef] [PubMed]

68. Tejwani, S.; Kolari, R.S.; Sangwan, V.S.; Rao, G.N. Role of amniotic membrane graft for ocular chemical and thermal injuries. Cornea 2007, 26, 21-26. [CrossRef]

69. Tseng, S.C. Amniotic membrane transplantation for ocular surface reconstruction. Biosci. Rep. 2001, 21, 481-489. [CrossRef] [PubMed]

70. Basu, S.; Mohamed, A.; Chaurasia, S.; Sejpal, K.; Vemuganti, G.K.; Sangwan, V.S. Clinical outcomes of penetrating keratoplasty after autologous cultivated limbal epithelial transplantation for ocular surface burns. Am. J. Ophthalmol. 2011, 152, 917-924. [CrossRef] [PubMed]

71. Burcu, A.; Yalniz-Akkaya, Z.; Ozdemir, M.F.; Erdem, E.; Onat, M.M.; Ornek, F. Surgical rehabilitation following ocular chemical injury. Cutan. Ocul. Toxicol. 2014, 33, 42-48. [CrossRef] [PubMed]

72. Salvador-Culla, B.; Kolovou, P.E.; Arzeno, L.; Martínez, S.; López, M.A. Boston keratoprosthesis type 1 in chemical burns. Cornea 2016, 35, 911-916. [CrossRef] [PubMed]

73. De la Sen-Corcuera, B.; Montero-Iruzubieta, J.; Sánchez-Ávila, R.M.; Orive, G.; Anitua, E.; Caro-Magdaleno, M.; Merayo-Lloves, J. Plasma rich in growth factors for the treatment of cicatrizing conjunctivitis. Clin. Ophthalmol. 2020, 14, 1619-1627. [CrossRef] [PubMed]

74. Dua, H.S.; King, A.J.; Joseph, A. A new classification of ocular surface burns. Br. J. Ophthalmol. 2001, 85, 1379-1383. [CrossRef] [PubMed]

75. Pfister, R.R. Chemical injuries of the eye. Ophthalmology 1983, 90, 1246-1253. [PubMed]

76. Roper-Hall, M. Thermal and chemical burns. Trans. Ophthalmol. Soc. UK 1965, 85, 631-653. [PubMed]

77. Ang, A.Y.; Chan, C.C.; Biber, J.M.; Holland, E.J. Ocular surface stem cell transplantation rejection: Incidence, characteristics, and outcomes. Cornea 2013, 32, 229-236. [CrossRef] [PubMed]

78. Ono, K.; Yokoo, S.; Mimura, T.; Usui, T.; Miyata, K.; Araie, M.; Yamagami, S.; Amano, S. Autologous transplantation of conjunctival epithelial cells cultured on amniotic membrane in a rabbit model. Mol. Vis. 2007, 13, 1138-1143.

79. Pellegrini, G.; Dellambra, E.; Golisano, O.; Martinelli, E.; Fantozzi, I.; Bondanza, S.; Ponzin, D.; McKeon, F.; De Luca, M. p63 identifies keratinocyte stem cells. Proc. Natl. Acad. Sci. USA 2001, 98, 3156-3161. [CrossRef]

80. Talbot, M.; Carrier, P.; Giasson, C.J.; Deschambeault, A.; Guérin, S.L.; Auger, F.A.; Bazin, R.; Germain, L. Autologous transplantation of rabbit limbal epithelia cultured on fibrin gels for ocular surface reconstruction. Mol. Vis. 2006, 12, 65-75.

81. Luengo, F.; Lavigne, V.; Gatto, S.; Groxanto, J.O.; Correa, L.; Gallo, J.E. One-year follow-up of epithelial corneal cell sheet allografts mounted on platelet poor plasma in rabbits. Mol. Vis. 2009, 15, 2771-2779.

82. Cheng, J.; Zhai, H.; Wang, J.; Duan, H.; Zhou, Q. Long-term outcome of allogeneic cultivated limbal epithelial transplantation for symblepharon caused by severe ocular burns. BMC Ophthalmol. 2017, 17, 1-10. [CrossRef]

83. Nakamura, T.; Inatomi, T.; Sotozono, C.; Koizumi, N.; Kinoshita, S. Ocular surface reconstruction using stem cell and tissue engineering. Prog. Retin. Eye Res. 2016, 51, 187-207. [CrossRef] [PubMed]

84. Gupta, N.; Joshi, J.; Farooqui, J.; Mathur, U. Results of simple limbal epithelial transplantation in unilateral ocular surface burn. Indian J. Ophthalmol. 2018, 66, 45-52. [CrossRef] [PubMed]

85. Sangwan, V.S.; Sharp, J.A.H. Simple limbal epithelial transplantation. Curr. Opin. Ophthalmol. 2017, 28, 382-385. [CrossRef]

86. Sacchetti, M.; Rama, P.; Bruscolini, A.; Lambiase, A. Limbal stem cell transplantation: Clinical results, limits, and perspectives. Stem Cells Int. 2018, 18. [CrossRef] [PubMed]

87. Sangwan, V.S.; Basu, S.; Vemuganti, G.K.; Sejpal, K.; Subramaniam, S.V.; Bandyopadhyay, S.; Krishnaiah, S.; Gaddipati, S.; Tiwari, S.; Balasubramanian, D. Clinical outcomes of xeno-free autologous cultivated limbal epithelial transplantation: A 10-year study. Br. J. Ophthalmol. 2011, 95, 1525-1529. [CrossRef] 
88. Zakaria, N.; Possemiers, T.; Dhubhghaill, S.N.; Leysen, I.; Rozema, J.; Koppen, C.; Timmermans, J.P.; Berneman, Z.; Tassignon, M.J. Results of a phase I/II clinical trial: Standardized, non-xenogenic, cultivated limbal stem cell transplantation. J. Transl. Med. 2014, 12, 58-69. [CrossRef]

89. Rahman, I.; Said, D.G.; Maharajan, V.S.; Dua, H.S. Amniotic membrane in ophthalmology: Indications and limitations. Eye 2009, 23, 1954-1961. [CrossRef]

90. Anitua, E.; Muruzabal, F.; Tayebba, A.; Riestra, A.; Perez, V.L.; Merayo-Lloves, J.; Orive, G. Autologous serum and plasma rich in growth factors in ophthalmology: Preclinical and clinical studies. Acta Ophthalmol. 2015, 93, e605-e614. [CrossRef] 